\title{
A memória dos lugares, dos objetos e os guardiões da memória na educação não-formal*
}

\author{
Renata Sieiro Fernandes**
}

Estou acostumada a organizar as lembranças da minha vida em torno de um rol de namorados e de livros. Os diversos relacionamentos que tive $e$ as obras que publiquei são as referências que marcam minha memória, transformando o ruido informe do tempo em uma coisa ordenada. "Ah, aquela viagem ao Japão deve ter sido na época em que eu estava com J., pouco depois de escrever Te tratarei como uma rainha", penso e imediatamente as reminiscências daquele periodo, as desgastadas migalhas do passado, parecem instituir-se em seu lugar. Todos os seres humanos recorrem a truques parecidos; sei de gente que conta sua vida pelas casas em que morou, ou pelos filhos, empregos e até mesmo pelos carros. (Montero, 2004, p. 7).

As rememorações podem partir de muitos lugares, de objetos, de situações. Podem ser provocados ou emergir involuntariamente motivadas por qualquer evento externo.

* Este texto é uma parte revista e resumida de um capítulo de minha tese de doutorado defendida em 2005, sob orientação da Profa. Dra. Olga Rodrigues de Moraes von Simson.

** Pedagoga, professora de ensino fundamental, mestre e doutora pela Faculdade de Educação Unicamp 
Vi que M. também começava a sorrir enquanto ia enfocando a lembrança, ao se aproximar da pequena luz que acabava de se acender no fundo do seu cérebro; até que, de repente, sua memória se abriu; e vi que o passado lhe atravessava o rosto como a sombra de uma nuvem (Montero, 2004, p. 34).

Em um sábado de dezembro de 2000, em uma tarde de muito calor, em um canto da arena do Projeto Sol Monte Alegre, em Paulínia-SP, um encontro reuniu dois rapazes e sete moças (e cinco acompanhantes, sendo dois filhos pequenos e três namorados/as), jovens ex-freqüentadores do Projeto Sol, uma das educadoras (Nilza) do Projeto e esta pesquisadora com o objetivo de propiciar um momento de evocação de experiências passadas vividas com o grupo, há pelo menos dez anos, sob o enfoque dos trabalhos desenvolvidos conjuntamente e, brevemente, tentar estabelecer relações iniciais com suas formas de inserção social na atualidade.

Essa intenção e atitude justificam-se em função de apresentar o Projeto Sol como uma experiência educativa para crianças e jovens de baixo poder aquisitivo, ocorrendo paralelamente à escola, de caráter formador e voluntário, com resultados positivos a curto, médio e longo prazo.

A forma de se chegar a esses dados, a partir de elementos extraídos de um cotidiano já vivido e registrados na memória de cada um, sob modos diferenciados, se dá a partir de oportunidades para se falar sobre o ocorrido e o sentido, re-elaborando-os e ressignificando-os. Neste caso, a metodologia da História Oral torna-se fundamental, pois permite o conhecimento da reconstrução das vivências e experiências (muitas vezes no decorrer do diálogo estabelecido entre entrevistador e depoente), em razão das condições que os momentos da entrevista oferecem. Por fazer parte de uma história e memória recentes, esses conteúdos não são ainda conhecidos e nem interpretados mais detidamente, daí, novamente a relevância da contribuição da História Oral como forma de acesso a essas lembranças e esquecimentos.

Os critérios para a escolha dos depoentes basearam-se nas seguintes condições: que fossem ex-freqüentadores que houvessem participado do Projeto Sol durante um período de tempo de, aproximadamente, sete anos (pois a faixa etária atendida nessa instituição abrangia o intervalo de 7 a 14 anos); que houvesse ex-freqüentadores que tivessem participado 
desde os primórdios do Sol (sua inauguração data de 1988); que houvesse ex-freqüentadores de cada um dos quatro núcleos de Projeto Sol, assentados nos bairros: Morumbi, Monte Alegre, Morro Alto e João Aranha; que representassem os gêneros masculino e feminino; e que representassem etnias diversas (branca, parda/mulata e negra). ${ }^{1}$

Quem serviu como mediadoras foram quatro ex-educadoras do Projeto Sol que trabalharam em diferentes períodos da existência deste. Elas fizeram os contatos com os jovens e me colocaram em proximidade com eles. A partir de então, eu e os grupos ou os sujeitos, individualmente, nos organizávamos para os encontros.

Usei, basicamente, o gravador para registrar as falas (e depois transcrevê-las) e um caderno de campo para anotar as informações gerais, hipóteses e percepções. Apenas em um momento me vali do vídeo para gravar as cenas de entrevistas com um grupo grande de jovens - que é o caso a que me refiro neste artigo.

Esses jovens, então, partiram de suas memórias sobre um momento de suas vidas, mais especificamente ligado a um processo formativo institucional, diferente da educação formal que deixa algumas marcas na biografia de seus sujeitos. Tais marcas vividas e sentidas referem-se às experiências em um espaço educativo não-formal, ocorrida nos quatro núcleos de Projeto Sol, oferecidos pela Secretaria de Educação da cidade de Paulínia até meados do ano de 2000.

A memória desses sujeitos foi provocada deliberadamente, a partir de intervenções e sugestões por parte da educadora e desta pesquisadora, bem como a partir do manuseio de materiais que servissem de elo com esse passado recente - não mais do que dez anos -, e que pudessem provocar lembranças, como: fotografias do grupo trabalhando, brincando, se apresentando; trabalhos registrados por escrito e imageticamente pelo grupo; vídeos filmados durante apresentações, passeios, festas, confraternizações, fantasias usadas em teatros e danças etc. Esses materiais, que funcionaram como suporte para a memória, foram apresentados aos jovens, gradativamente, em momentos diferentes e após um certo esgotamento do período das conversas.

1 No total da pesquisa foram entrevistados 15 ex-freqüentadores, sendo sete do sexo masculino e oito do sexo feminino. Eles incluem-se na faixa etária dos 18 aos 23 anos. 
Proust (apud Brito, 1989) fala de dois tipos de memória: a involun tária e a voluntária. A primeira, "nunca parte de um desejo determinado de manipular o passado com vistas à sua possível utilização no presente”. Para ele, a memória voluntária não alcança seus objetivos plenamente porque possui, na sua origem, uma idéia preconcebida do que se quer encontrar. A outra, "ao contrário, advém de uma sensibilidade difusa e inesperada que pode acometer o homem a qualquer momento, levando-o a reviver flashes do seu passado, em todo o seu colorido original" (Ibidem, p. 18).

Nesse encontro com ex-freqüentadores do Projeto Sol, o que vieram à tona no processo de rememoração, foram lembranças provindas da memória voluntária, já que houve a construção do momento do encontro com objetivos bem definidos do que se gostaria de provocar nesses sujeitos. Embora Proust não valorize tanto esse tipo de procedimento, ele é tão válido quanto essencial, pois permite ao narrador verbalizar como os fatos lhe aparecem e, ao ouvinte permite conhecer como os fatos são contados (quando são eleitos ou quando deixam de ser) e reapresentados, isto é, como são trazidos novamente para o presente, incluindo-se aí o uso da imaginação que se junta ao fato ocorrido, pois as lembranças não aparecem exatamente como aconteceram no passado. Segundo Halbwachs, “o passado já não se apresenta numa forma 'pura' mas, sim alterado pela leitura que o presente faz dele" e continua dizendo, "que a memória é releitura e reconstrução do que passou, a partir da inserção do indivíduo numa coletividade e em momentos presentes que se sucedem" (Ibidem, p. 19).

Logo, o que foi evocado surgiu a partir de uma deliberada e intencional provocação, tanto através de perguntas como da visualização e manipulação de materiais que agiram como possíveis disparadores de lembranças. Esses últimos podem, inclusive, ser tidos como "memória do papel”, conforme diz Brito (Ibidem, p. 12) citando Leibniz, um filósofo e matemático do século XVIII, para quem a materialidade e a visibilidade proporcionadas por esses suportes funcionam como registro e cristalização de momentos acontecidos, que guardam em si resquícios de algo que, de fato, se passou e, que são passíveis de serem complementados com outras informações que quem os manipula possui.

A ameaça do esquecimento provoca a busca da preservação, "[...] a esses registros é confiada a tarefa de lembrar e conservar o lembrado" 
(Brito, 1989, p. 14). Entretanto, as "leituras" ou as interpretações proporcionadas só podem acontecer para quem, de alguma forma, possui relação com o que está sendo visto ou ouvido (imagens, sons), desde que o conteúdo ou fragmentos do conteúdo - porque o que são preservadas são parcelas do real, não a sua totalidade - permitam suscitar algum significado para o leitor ou o ouvinte, o que significa dizer, que essas "leituras" só acontecem se são possuídas as "chaves" que facilitam o entendimento.

Pierre Nora, falando sobre os lugares da memória, diz que "quando a memória não está mais em todo lugar, ela não estaria em nenhum lugar se uma consciência individual, numa decisão solitária, não decidisse dela se encarregar. Menos a memória é vivida coletivamente, mais ela tem a necessidade de homens particulares que fazem de si mesmos homensmemória" (Nora, 1993, p. 18).

Tal afirmação possibilita ver essa educadora, a Nilza, em particular, como uma guardiã da memória de grupos com os quais conviveu, que por iniciativa própria, mobilizada por interesses e necessidades individuais (o seu desejo de não esquecer, de guardar o que foi significativo), mas também sociais abre, no futuro, a possibilidade de tornar isso conhecido e partilhar sentidos com um público alheio, bem como garante o acesso aos ex-participantes envolvidos a uma parcela de sua memória biográfica.

Desse modo, os instantes e as situações, individuais e coletivos, selecionados para serem registrados em imagens iconográficas percorrem o caminho de uma memória geral para uma memória privada que os torna disponíveis, novamente, para apreensão social.

Nora ainda aponta um outro fator importante relacionado a essa passagem da memória geral para a privada; para ele, a memória privada "obriga cada um a se relembrar e a reencontrar o pertencimento, princípio e segredo da identidade” (Ibidem, p. 18). Pertencimento esse reforçado pelos laços de amizade construídos no Sol.

Além da possibilidade de ver a pessoa da educadora citada como um "lugar de memória", pela atribuição de guardiã que ela se autocoloca, pode-se incluir o Sol como um lugar desse tipo, pois este se enquadra na definição dada por Nora (Ibidem, p. 21): "são lugares, com efeito, nos três sentidos da palavra, material, simbólico e funcional, simultaneamente, somente em graus diversos. Mesmo um lugar de aparência puramente material, como um depósito de arquivos, só é lugar de memória se a imaginação o investe de uma aura simbólica” . 
Primeiramente, é material porque existe de fato ainda hoje, em quatro bairros periféricos, com uma arquitetura peculiar, misto de circo e anfiteatro grego (embora, atualmente, assumindo a função de espaço escolar, formal). ${ }^{2}$ Em segundo, é simbólico porque é um espaço educativo, onde acontecem práticas de trabalho e onde são construídas relações pessoais que provocam uma ligação maior ou menor, mais ou menos afetiva com o espaço. Em terceiro, é funcional porque é um espaço de convivência, de socialização e de sociabilidade e, também é educativo onde o aparecimento de desejos, necessidades, vontades e curiosidades dá o mote para a discussão e elaboração de práticas de trabalho de pesquisa e criação, de conhecimento de si, do outro e do mundo, de uma forma diferente, ampliada, daquela experimentada no ambiente da educação formal.

Embora o Sol não tenha sido criado/construído com a finalidade e com a intenção de perpetuar a memória (como são os museus, monumentos, etc), ele funciona como se fosse, na medida em que conserva em si e socializa fragmentos de experiências e vivências passadas e que permitem, na atualidade, a reconstrução de significados. Isso porque em seu espaço coexistem e se relacionam pessoas e objetos, e são aquelas que têm o potencial para dar continuidade e inteligibilidade e podem ressignificar as práticas que lá ocorrem. Como "a memória significa, quer dizer, atribui significado as coisas para que sejam portadoras de idéias, valores e normas sociais" (Mauad, 1997, p. 313), as imagens que ela exterioriza (verbais e orais) são representações que permitem interpretações de parcelas da realidade, pois trazem para o presente, na forma de substituto, como diz Mauad, uma realidade ausente. Portanto, o Sol pode ser visto como lugar $d a$ memória. Por outro lado, pode ser visto também como lugar de memória, no caso em que não apenas se recorda e se fala dele, mas estando nele, como aconteceu nesse encontro, quando estávamos no Sol para falar dele, das marcas que as vivências nesse espaço deixaram na memória dos sentidos de seus exfreqüentadores.

Gagnebin (1998, p. 218) pergunta em seu texto: "por que a reflexão sobre a memória utiliza tão freqüentemente a imagem - o conceito - de rastro?" E ela propõe a resposta: "Porque a memória vive essa tensão

2 Sobre essa ressignificação das funções do Sol, passando de espaço de educação não-formal para de educação formal, ver Fernandes, 2001, p. 59-70. 
entre a ausência e a presença, presença do presente que se lembra do passado desaparecido, mas também presença do passado desaparecido que faz sua irrupção em um presente evanescente".

Mauad (1997) também fala sobre o trabalho de reflexão e busca de interpretação sobre "vestígios" de objetos e lembranças, de realidades presentes e viventes. Mais à frente, fala de "pistas" e "índices" provenientes de imagens verbais e não-verbais que permitem, pelos fragmentos, uma busca de lógica explicativa em um determinado tempo e espaço.

Rastros, vestígios, pistas, índices... são termos sinônimos que autorizam, por um trabalho cuidadoso de indução permeado pela intuição e pela imaginação, concluir a existência de circunstâncias que encontramse obscurecidas mas, relacionadas a circunstâncias conhecidas.

Ginzburg, em seu método de trabalho em história, reconstrói eventos envolvendo-os no pensamento de homens e mulheres em diferentes contextos sociais e culturais, que existiram em épocas passadas. Em um trabalho minucioso de pesquisa a partir de resquícios que persistem na atualidade repete o que o homem tem feito na sua busca para entender a si e o mundo.

Sobre isso, diz o autor em um de seus escritos:

Por milênios o homem foi caçador. Durante inúmeras perseguições, ele aprendeu a reconstruir as formas e movimentos das presas invisíveis pelas pegadas na lama, ramos quebrados, bolotas de esterco, tufos de pêlos, plumas emaranhadas, odores estagnados. Aprendeu a farejar, registrar, interpretar e classificar pistas infinitesimais como fios de barba. Aprendeu a fazer operações mentais complexas com rapidez fulminante, no interior de um denso bosque ou numa clareira cheia de ciladas. Gerações e gerações de caçadores enriqueceram e transmitiram esse patrimônio cognoscitivo. (Ginzburg, 1989, p. 151).

Essa forma de interpretar vestígios adquire uma formulação mais metódica de trabalho para, por exemplo, Freud, Sherlock Holmes e Morelli, citados pelo autor. Os três valem-se de "um método interpretativo, centrado sobre os resíduos, sobre os dados marginais, considerados reveladores" (Ibidem, p. 150-151). Desse modo, pormenores normalmente considerados sem importância, ou até triviais, seriam fundamentais 
para se interpretarem questões colocadas no cotidiano, para o indivíduo e/ou para o grupo. ${ }^{3}$

Com a memória da situação vivida ${ }^{4}$ - o encontro - e com a transcrição das entrevistas em mãos pude perceber, primeiramente, que esses jovens não apresentam uma reflexão mais acurada sobre a importância do Sol em suas vidas, parecendo indicar uma falta ou não necessária preocupação imediata com essa problemática que me interessa. Entretanto, todos são unânimes em dizer que as vivências no Sol foram muito importantes, mas as explicações não lhes são tão claras. Aos poucos os sentidos vão sendo construídos, porém, nem sempre serão incorporados na fala, ou seja, eles estarão sutilmente presentes embora não tão evidentes.

Em geral, lembram-se de fatos e sensações ocorridas no momento e falam de sentimentos, reavaliados hoje, provocados por essas vivências.

A princípio, as lembranças são tímidas e poucas, seguidas de alguns "ah, eu não me lembro, me foge..." Da mesma forma, as explicações que dão são fluídas em detalhes porém, repletas de emoção, como se vê abaixo:

Educadora: Que mais vocês lembram? Isso foi importante pra vida de vocês?

Alessandra, Valquíria, Alcione: Foi.

(André responde com a expressão “iche!!”)

Educadora: Por quê?

3 O autor vê uma analogia entre os métodos de interpretação utilizados pelos três personagens citados através de "pistas talvez infinitesimais (que) permitem captar uma realidade mais profunda, de outra forma inatingível" (p. 150). As pistas, para cada um dos três, são as seguintes: para Freud equivalem aos sintomas desencadeados por doenças e indicativos do estado psicológico do indivíduo; para Holmes equivalem aos indícios que auxiliam na decifração de casos policiais; para Morelli equivalem a signos pictóricos buscados para identificar traços imitados ou forjados por pintores em obras de arte cuja autoria é atribuída a um pintor famoso ou respeitável.

4 A educadora, a pesquisadora e a diretora do núcleo - que fez a gravação em vídeo - organizamos a arrumação do espaço para o encontro e a entrevista, com cadeiras e com o material de gravação previamente a chegada dos rapazes e garotas. Uma inesperada situação nos fez mudar os planos traçados. Havíamos pensado em reunir o grupo próximo ao refeitório, coberto e com cadeiras. Entretanto, conforme as pessoas foram chegando, dirigiram-se para a arena - local tradicional de encontro para a organização dos trabalhos cotidianos, dentro das rotinas do Sol - e por lá ficaram. Esse fato foi interessante pois provocou em nós a necessidade de irmos ao encontro deles e não o contrário, pegando-nos de surpresa e exigindo, assim, uma flexibilidade e uma readequação de nossas posturas. A construção da relação da pesquisaa começou ali. Esse é mais dos lugares da memória pois além de ser significativo simbolicamente, foi de lá que os jovens falaram, ou seja, estando dentro da própria arena. 
André: Ah, sei lá... pra gente mudar um pouco.

Educadora: Então, o André falou que foi super importante...

André: Noossa... acho que pra todo mundo, né?

Educadora: E pro Leônidas?

Leônidas: Também.

Educadora: Por que, Leônidas?

André: Não sabe mais, né?

Obviamente, uns se lembram mais e melhor do que outros e verbalizam da mesma forma. ${ }^{5}$ Dois casos destoaram do restante do grupo: uma moça que, dentre todos, é a que melhor elaborou suas memórias e melhor as exteriorizou e o outro é um rapaz, tímido, que pouco falou e se expressou, porém, o fez através da fala da namorada que o acompanhava. Disse por ele a namorada:

André: Ah, eu não me lembro...

Regiane: Acho que sim, que ele começou a falar "ah, o tempo que eu era feliz e não sabia" e começou a contá a vida inteira dele aqui pra mim.

Por vezes a memória falha e não permite a precisão da informação: "eu não lembro se eu dancei a Dança dos Velhos".

Outras vezes, a memória confunde, quase "trai", misturando pessoas e situações:

Patrícia: Em qual dos teatros que a Michelle levava uma surra de papelão, uma cinta de papelão, qual que era?

5 Monteiro (2004, p. 158-159), inventando uma classificação para os diferentes modos de escrita em relação aos modos de se lidar com a memória diz: "Eu também inventei minhas próprias categoria; uma delas, por exemplo, é a que divide os escritores entre os memoriosos e amnésicos. Os primeiros são aqueles que constantemente fazem alarde da própria memória; na certa são seres nostálgicos do seu passado, quer dizer, da infância, que é o passado primordial e originário; seja como for, os memoriosos têm um estilo literário meio descritivo, reminiscente, cheio de móveis, objetos e cenários carregados de significado para o autor e desenhados em seus menores detalhes, porque se referem a coisas reais petreamente instaladas na lembrança... Os autores amnésicos, em contrapartida, não querem nem podem recordar; seguramente fogem da própria infância e sua memória é como um quadro-negro mal apagado, cheio de borrões incompreensíveis... Estão mais concentrados na atmosfera, nas sensações, na ação e na reação, no metafórico e emblemático". 
Educadora: Ele era o Birico (personagem do teatro) e o Charles? Lembra o nome do (personagem) do Charles?

Patrícia: Ah, eu não me lembro, me foge...

Em outros momentos, a aparência física das pessoas, aspectos afetivos ligados a elas ou a situações, permanecem, persistem na memória:

Educadora: Eu não esqueço do vô da Karina, lembra? O vô da Karina ficava aqui na... em frente à casa dela, não sei se vocês lembram?

André: Ah, eu lembro!

Patrícia: Ah, eu lembro sim!

Educadora: De bengalinha, assim (faz um gesto), a Geige desenhou(-o).

Geige: Chinelo de dedo...

Outro ponto importante que também aparece está ligado à memória sonora, musical:

Alessandra: E a música... de vez em quando eu lembro como canta, mas tem hora que some tudo as letra.

Patrícia: Ah, quando eu ouço aquela música, nossa... você viaja. Alessandra: Eu lembro das músicas, aí eu fico lá cantando, só que tem vez, sabe quando vem de repente na cabeça da gente a música... tem dia que eu canto ela inteirinha, daí outras vez eu nem sei nem começar a música.

As lembranças de uns provocam associações em outros, que geram novas lembranças de melodias, de letras de músicas de MPB que, talvez eles não tivessem conhecimento fora do Sol. Esse repertório ampliado foi proporcionado pela educadora que as incluiu em seus trabalhos de teatro ou simplesmente pelo prazer de ensinar a apreciar e divulgar uma bela letra e uma bela melodia, cantada, nesse caso, por Caetano Veloso, Milton Nascimento ou Pena Branca e Xavantinho.

Segundo o que contam, o Sol lhes possibilita o contato com repertórios culturais de um universo alheio ao seu, ao qual o acesso não é tão imediato, tido como "cultura de elite ou erudita". Não priorizam falar do 
espaço que o Sol garante para exporem conteúdos e conhecimentos próprios de seus contextos culturais; antes, preferem enfatizar aquilo com que tomaram contato, com o novo, com a novidade, representando um enriquecimento e ampliação de seus repertórios. E isso relacionado, principalmente, às artes, à música e à pintura, que são preferências particulares da própria educadora com que se envolveram.

Sobre esse ponto, dizem as garotas:

Michelle: Eu acho assim, que nem, como eu participava muito da sua sala, porque a gente que não tem uma condição social mais elevada, é um meio de adquirir cultura. Porque eu conheci pintores: Van Gogh, Renoir, Monet... Hoje eu gosto disso, de música clássica, eu gosto de MPB por causa daqui: porque eu entrei em contato com isso, porque a minha mãe é simples, o meu pai também, então não é que eles não gostavam, eles não conheciam esse tipo de informação pra trazer pra gente, então eu tive isso aqui. Então, hoje eu gosto de ler sobre arte, eu quando eu posso, vou lá no MAC (Museu de Arte de Campinas) visitar, eu participo do Clube da Cultura, só não 'tô indo nas viagens por causa do Rômulo (seu bebê recém-nascido), né. Então, isso foi muito importante, pra entrar em contato com a arte mesmo, 'tá conhecendo, se interessando...

Patrícia: O gosto pela dança, as coisas por teatro...

Alcione: Folclore... as coisas que a gente aprendeu aqui, se fosse pra gente aprender em outro lugar, na rua, ia ser difícil...

Michelle: A gente não ia ter oportunidade... ou na faculdade, ou aqui, né?

É interessante observar que, para a Michelle, suas únicas possibilidades de acesso a um repertório tido como pertencente a um grupo de nível sócio-econômico elevado dizem respeito a dois lugares, o próprio Sol como favorecedor desse contato e, a Faculdade como uma depositária desse conhecimento e acessível a quem chega a seus espaços, difíceis de serem conquistados para aqueles que provêem de meios menos favorecidos economicamente. Desse modo, a chance imediata foi obtida no Sol e a Faculdade fica como espaço da projeção do desejo oscilando entre o possível e o inalcançável. 
Quando falam das experiências passadas no Sol não deixam de falar nas da escola. O que serve de engate para unir os discursos de ambos os espaços é a frase: eu vi primeiro no Sol, veladamente denunciando uma falha no modo como a educação formal tem encaminhado suas práticas.

Valquiria: Lembra daquele livro que você deixava na sala pra gente ver? Uma vez eu fui lá na Bienal das Artes, com a escola... Eu lembrava das figuras por causa do livro...

Michelle: E a gente via o que a gente via no livro e depois chegou lá e viu, né? Então, eu fico assim, sabe... nossa, eu lembro bem do Sol, agora eu 'tô vendo aqui Van Gogh, né. Puxa, você pára, que nem eu... nossa! Eu sou louca, eu adoro Van Gogh, e me emocionou muito porque eu entrei em contato aqui, né e chegou lá na Bienal... Nossa! Eu 'tô vendo de perto, putz, quanta gente já não viu isso no mundo inteiro, né, e eu vi lá no Sol primeiro, agora aqui... Nossa, não tem nem como explicar, arte é aquele negócio, não dá pra gente explicar, a gente sente, mexe.

A relação afetiva construída com os adultos também marca uma diferença da estabelecida por eles com a escola e os professores;

Pesquisadora: O que vocês lembram da relação com os adultos que 'tavam aqui, com as educadoras? Come é que foi essa influência, das educadoras e dos educadores? Em que eles influenciaram em vocês, que lembranças vocês têm dessa relação, com essas pessoas que estavam aqui na época?

Geige: Ah, não era aquela coisa assim... de professora manda... era mais amigo. Tinha mais amizade, não era assim autoritário, de mandar...(do tipo) "eu mando você fazer isso e você faz", não... era uma, uma amizade.

Alessandra: Não era que nem escola.

Patrícia: A gente brincava um com o outro.

Valquiria: [...] aqui, não era aquela coisa do professor autoritário e o aluno tem que obedecer, aqui a gente dividia as coisas. Não é a mesma emoção porque, na escola, você tinha que fazer... por exemplo, você tinha que ganhar nota, um ponto naquilo, né, sabe... 'tá entendendo o que eu quero dizer? E aqui não, você ia porque 
você queria, você ia, você aprendia, você cantava, você dançava porque você queria, você gosta, tava gostando de fazer aquilo. $\mathrm{Na}$ escola não. Então, eu acho que é uma emoção, mas é diferente daquela "ai, meu Deus, será que eu vou errar? Será que eu não vou?” Mas é uma coisa diferente daqui, você entendeu, né?

A comparação dos espaços do Sol e da escola é inevitável e, ao proceder dessa forma, aproximam-nos. Porém, na realidade, os espaços são distintos e envoltos em universos diferentes. Isso é mostrado, por exemplo, na fala a seguir, em que Valquiria se dá conta, através do registro fotográfico que permite o reconhecimento de um colega, que não havia percebido que os dois dividiam ambos os espaços.

Valquiria: Tem gente que eu conheço, que 'tá aqui na foto só que eu não lembro que estudava junto aqui comigo, por exemplo, o Paulinho, um moreninho. Não sei se você lembra, (se) vocês lembram do Paulinho? Tem uma foto aqui dele, e eu estudava... o ano passado ele se formou junto comigo, em Administração. Acho que foi, e eu lembro de ter amizade com ele mas, eu não me lembro (dele) daqui. Agora eu vi a foto (e pensei) "nossa, o Paulinho 'tava no Projeto Sol também!".

Ao contarem do que lembram e quais os efeitos provocados neles ao participarem das atividades desenvolvidas no Sol, é possível apreender das falas outros aspectos como: influência positiva no âmbito pessoal, no social, no processo de construção de conhecimento, nas oportunidades de vivências de vários tipos.

No âmbito pessoal, as influências se deram na modificação da personalidade e na construção da auto-estima, principalmente.

Michelle: Eu sempre fui uma criança muito tímida, inibida, né, que não conseguia me expressar. Eu acho que foi muito importante a parte do teatro, da música, pra eu aprender, pra poder aprender a me soltar e ver que eu era capaz de fazer as coisas, que eu era uma pessoa que tinha... eu era... a minha auto-estima era baixa, eu via que era capaz de criar, que eu podia fazer as coisas. Então, foi muito importante. 
Valquiria: Eu acho que foi muito importante, porque você aprende a atuar, você aprende, né Alcione, a não ter vergonha, é... a não ter vergonha.

Além da influência positiva na personalidade, falam também de construção de autonomia, de responsabilidade, de sustentação de argumentos e de sua repercussão no grupo.

No âmbito pessoal, as influências notadas são na melhoria da percepção e na relação com o outro, os pares ou mais velhos, através da forma adotada para a construção dos trabalhos e no momento de almoço.

Alessandra: Tinha esse negócio... a união. Por exemplo, a Geige
'tava fazendo uma coisa, terminou, ela vinha, ajudava eu, a Alcione,
eu, como sempre era a atrasada pra terminar as coisas... Andreza: Lembra que não podia jogar o resto (da comida) fora? Se sobrasse muito tinha que comer? As meninas fizeram eu pegar um monte, e depois eu não consegui comer. Tive que comer tudo forçada, na primeira vez que eu vim. Nossa!

Alessandra: Já foi uma parte do ensinamento: que nóis nunca deve encher o prato! Colocar a quantia certa de comer, não é? (risos). Coisa feia. E aqui a gente aprendeu isso.

No âmbito da construção de conhecimento (de si, do outro e em geral), o privilégio que tiveram de se envolverem em processos de criação (individual e/ou coletiva) e na elaboração e confecção de produtos finais é o que mais marca esses ex-freqüentadores. Outra influência positiva, segundo contam, é que aprenderam a trabalhar de forma organizada, segundo planejamentos e com a preocupação de pôr em prática e finalizar os projetos.

Patrícia: Não tinha texto (no caso do teatro), não era aquela coisa assim que a gente tinha que falar (meio decorado)...

Michelle: A gente montava os textos, né? O Teatro dos Bonecos foi assim, foi surgindo.

Alcione: E isso deixava a gente mais solta, pra fazer uma coisa melhor. Sei lá, ia liberando tudo, ia fazendo, ia criando, daqui a pouco saía uma coisa bonita, que a gente nem esperava que ia fazer aquilo, né? 
Valquiria: Eu acho legal o improviso porque quer dizer que a gente aprendeu também, o improviso é uma aprendizagem, né? Por exemplo, se você esquece na hora (a fala), alguns toques... você vai falar outra coisa, porque você viu assim, tem gente (que faz) assim.

Michelle: E acaba saindo até mais autêntico, não é aquela coisa mecânica.

Valquiria: É. A gente sabia a história.

Educadora: Como vocês passavam a história dependia de vocês.

Valquiria: É. Do jeito que a gente tinha sentido. Cada um tinha aprendido de um jeito.

Alessandra: (O Sol) muda a vida de qualquer um que (o) freqüenta, organiza até o jeito da gente ser. A gente presta atenção em quem não foi criado em ambiente assim, a gente tem um modo de vista, de ver uma coisa e fazer [...]. "Pra começar a fazer uma coisa, a gente tem que ir até o fim”. Agora não, tem uns que começa e larga. Assim não é... no meu jeito de pensar não é. Não foi o que eu aprendi. E ainda, até quando eu vejo as coisa assim errada eu quero corrigir, mas não tem como, porque eu me sinto assim, ó, eu aprendi foi desse jeito e o certo é continuar, não voltar pra trás e largar aquilo ali...

$\mathrm{O}$ fato do ato de aprender poder estar associado ao prazer e à descoberta, envolvendo um ato criativo, é o que torna o trabalho significativo, ao ponto, inclusive, de se manter uma relação forte de afetividade com o produto criado.

Educadora: E aquela vez que o Boi sozinho, 'cês lembram? Foi pra uma escola. Até vocês não queriam que ele fosse. E vocês agarravam o pescoço, e beijavam o Boi, e chorava em cima do Boi. Valquiria: Era um carinho que tinha por um pedaço de papelão...

“Mas era só um pedaço de papelão?”, pergunta a educadora. Não. Diz Alcione: "pra quem visse (era só um papelão), né, pra gente não. Existe algo a mais, que é o sentido agregado ao produto material. É como arremata Alessandra: É um pedacinho da gente ali, né?” E, depois, Alcione: "Com carinho, tudo (Valquiria acrescenta 'ciúmes'). A gente era apegado." 
Ao que se tem apego, se guarda, como a Alcione que tem guardado o desenho da Geige, "até hoje”, e como a educadora, a guardiã da memória do grupo, (que causa surpresa até mesmo para ele, conforme Alessandra comenta: “ah, a Nilza tem esse 'trem' guardado ainda?”), que tem consigo as listas de presença dos freqüentadores em diversas épocas, desenhos, livros de histórias inventadas ou reconstruídas, livros de registros do processo de execução de atividades de estudo e pesquisa, objetos que pertenceram a cenas de peças, feitos em oficinas, roupas de personagens de dança ou teatro, recortes de jornal em que o Sol aparece, muitas fotos e muitas imagens em movimento, de apresentações, festas, passeios, ensaios etc. Abaixo, um trecho da própria educadora falando de si como guardiã:

Educadora: Sabe uma coisa que eu lembro muito de você? Que num dia dos professores, a gente ganhou um cartão com um desenho seu (Andreza), lembra? Ele tinha o fundo inteirinho verde, daí, tinha eu acho... não sei se uma mulher, uma figura... Eu olho pra ela (e) eu lembro do cartão. Cada um me deixou várias lembranças. Eu lembro de personagens que fizeram, de coisas que participaram, de roupas, de desenhos, cada um tem um toque diferente.

Leônidas: Tem ainda aquele desenho que eu fiz com...

Educadora: Tenho, 'tá aqui no meu armário, eu já te pego... é de... de cerâmica, de barro, de argila.

No âmbito das vivências e experiências proporcionadas e ocorridas no Sol, aparece a afetividade ligada ao espaço e a relação com as pessoas do próprio Projeto (educadores e pares) - que provoca, hoje, desejos de reencontros - e da comunidade do entorno.

Regiane (namorada do André): Ele contou que ele chegava e ficava deitado aqui, olhando pra cima, que gostava, que adorava a comida daqui...

As conversas e o diálogo existente no cotidiano também merecem comentários valorizando as posturas adotadas pelos educadores: 
Valquiria: Eu acho que o importante era mais a conversação que vocês tinham com a gente, pra mostrar pra gente o lado diferente da coisa, né. Então, eu acho que essa conversa, a insistência de conversar aqui, conversar lá, mostrava o que vai acontecer, eu acho que é importante sim de mostrar, de conversar.

$\mathrm{E}$ as conversas citadas não dizem respeito apenas ao andamento do trabalho, mas de assuntos em geral, de necessidade e de interesse dos sujeitos, quando podiam exteriorizar suas preocupações e dúvidas e contar com o auxílio de um adulto mais experiente. Esse teor altamente positivo atribuído ao que foi possibilitado e vivenciado no Sol, em vários âmbitos, não é apenas dado por esses ex-freqüentadores; é respaldado pela aprovação e valorização familiar.

Michelle: Meu pai ficava mais orgulhosão ainda quando ele vinha assistir as apresentações. Ele adorava, ele sempre incentivou a gente a participar de grupos... 'tá participando de teatro... 'tá participando desse tipo de atividade (quer) fosse aqui, fosse na época que a gente mudou pro (bairro) João Aranha (onde existe outro núcleo de Projeto Sol), na igreja... Ele sempre gostou muito e, quando tinha as apresentações, o sorrisão era de orelha a orelha. Ele sempre incentivou muito.

As referências do Sol na vida deles são muito fortes e emotivas. Podese notar que houve ressonância disso no contexto interpessoal, e também houve repercussão no contexto externo, intrapessoal, passando pelo próprio grupo envolvido, pelos/as educadores/as e pela família, mas é possível supor que atinja a comunidade do entorno, embora não tenham abordado esse fato. Mais do que se sentirem satisfeitos com o que puderam vivenciar e com o que podem recordar disso, o desejo de muitos deles é poder proporcionar o mesmo tipo de experiência - ou semelhante -, principalmente, para os filhos. Esse é um ponto fundamental e que merece ser frisado, pois o desejo é para compartilhar algo que foi positivo e que influenciou sobremaneira seus modos de ser e lidar com pessoal e social.

Alessandra: É uma coisa que a gente pode passar pros filhos, o que a gente aprendeu, isso também é uma coisa impor(tante)... 
Que é uma coisa bonita que a gente fez, né? Só que tem uns que não quer saber disso não.

Alcione: [...] Eu tenho uma filha agora, o mundo que eu vivi aqui, eu quero o melhor pra ela, no mesmo nível, até melhor se possível, porque a gente sempre... eu vim aqui, eu aprendi, eu não perdi nada, eu só aprendi muito mais do que eu imaginava. Então, a gente 'tá se baseando nisso pra levar pra frente. Eu acho que só vai melhorar pra ela e pras pessoas que 'tão do lado. Pode ser um dos objetivos: levar adiante.

As experiências ocorridas no Sol são projetadas para o futuro, no desejo de que outros possam vivenciar situações e momentos parecidos, por considerarem uma experiência de vida importante a ser dividida e compartilhada.

O Sol permeia a vida dessas pessoas. Elas o levam consigo mesmo quando não freqüentam mais seu espaço físico.

A saudade e a sensação provocada ao retornar ao espaço, ainda que momentaneamente, aparecem nos diálogos a seguir. Estão falando do que o "espaço" do Sol lhes provoca e, não apenas do "local", que acaba ficando circunscrito aos limites físicos, geográficos e arquitetônicos; o espaço carrega consigo a aura de lugar.

Alessandra: [...] E na hora que eu entrei aqui, me deu uma sensação assim... parecia que 'tava voltando tudo ao passado. Eu falei assim, ai, parecia aquele dia, de manhãzinha, era... 7 hora, 8 hora que nóis entrava. Parecia que eu 'tava entrando aquela hora ali, só faltava assinar o caderno (de presença).

Patrícia: Ai... senti um arrepio, aquela alegria...

Acompanhando a sensação de estar de novo naquele lugar está o reconhecimento dele, as permanências, as mudanças em sua caracterização, naquilo que lhe dá identidade:

Alessandra: A Gei(ge), ela segurou até no meu braço, e aqui nóis ficou um tempo olhando aqui pra arena... Aí, nóis começou a falar: 'ali naquela sala era a Eliane (educadora), a Nilza, aquela (era) a sala de dança, ali era a sala de costura, aquela eu não lembro 
quem que era, e aqui era o Heraldo (educador). Aí, nóis ficamos falando cada um o que era.

Quando falam do espaço do Sol, não fazem referência direta à sua forma arquitetônica, entretanto, ela aparece implicitamente no discurso. O sentido dela é (re)tomado ao falarem da ocupação e do significado que dão ao que lá ocorria. Segundo Izaak Vaidergorn, o arquiteto do Sol, em conversa informal, o sentido da construção não é dado a priori; suas linhas, seus espaços, propõem algo, porém, é uma proposta aberta - não totalmente, mas com amplas gamas - que será preenchida pela interação com as pessoas que lá se encontrarão. Um indício que aponta para essa construção de significado, de forma positiva e satisfatória, no caso do Sol, pode ser depreendido da fala de Valquiria: “[...] ainda mais que você está num lugar gostoso, aquela coisa de satisfação de 'tá no lugar... aí, quando você vê, já passou tão rapidinho, ‘puxa, passou tão rápido’... é sempre assim, né? Quando a gente 'tá num lugar que a gente quer (quer) que a hora demore. Você olha no relógio e 'pô, sete horas, eu tenho que ir embora!"

Os sentidos não se encontram no presente; eles estão no futuro. A memória é do presente e, faz-se uso dela em uma tentativa de entender o próprio presente para, em seguida, fazer projetos para o futuro, como mostraram as mães nos seus desejos para os filhos (de continuidade da vivência no Sol). Do mesmo modo, diz Valquiria:

Ainda eu 'tava comentando com ele (o namorado) na hora que a gente 'tava vindo pra cá. Eu falei: 'sabe aquele tipo de pessoa, aquele tipo de coisa que você nunca esquece? Que você pode 'tá velhinho, que você vai lembrar? Então, é assim o Projeto Sol pelo menos pra mim, eu não sei pra vocês, né. Você passa perto (e) você lembra de alguma coisa, você 'tá conversando com alguém (e) você lembra de alguma coisa. Tem uma importância muito grande, só que a gente só dá valor mesmo quando a gente sai, né. E quando a gente 'tá (aqui), a gente participa, mas a gente não dá aquela importância, aquela fundamental mesmo. Quando a gente sai é que a gente sente aquilo, que foi mesmo importante.

Diz Pierre Nora (1993, p. 19) que, "sem dúvida, para que haja um sentimento do passado, é necessário que apareça um 'antes' e um 'depois" 
para que o presente surja reconduzido e atualizado; "para a história-memória de antigamente, a verdadeira percepção do passado consistia em considerar que ele não era, verdadeiramente, passado. Um esforço de lembrança poderia ressuscitá-lo" e o presente, então, apareceria significado, por essa "solda e ancoragem. [...] Trata-se menos de uma separação vivida no campo de diferença radical, do que um intervalo vivido no modo da filiação a ser restabelecida."

Essa sensação de "antes" e "depois", que marca uma noção de tempo passado, também aparece referendando percepções sobre mudanças no comportamento, ligadas as vivências passadas no Sol.

\begin{abstract}
Alcione: Eu acho que melhorou bastante o desempenho em casa também depois que comecei a freqüentar (o Projeto Sol). Comecei a fica ligada nos horários, o que 'tava fazendo em casa fazia aqui no Raio de Sol (nome do Projeto Sol nos seus primórdios), depois chegava em casa tinha que... já deixava assim meio organizado [...]. Então, eu acho que ficou..., acho que, estável, melhorou bastante em casa. $\mathrm{Na}$ época que eu vinha, eu lembro, acho que a minha cabeça ficou mais ocupada... acho que foi bom.
\end{abstract}

A fala acima demonstra um teor altamente positivo atribuído ao que foi vivenciado no Sol. A idéia do "antes" e "depois" do Projeto Sol aparece evidenciada no que a garota escolhe para contar sobre a influência dele em sua vida.

Mesmo estando ausente do seu espaço, a saudade dele provoca o interesse por se buscarem informações sobre sua existência atual, seu modo de funcionamento, as pessoas que permaneceram lá e as que saíram... Mesmo não se estando lá fisicamente, se está lá em pensamento, através do que ficou na memória e na saudade sentida.

As falas desses garotos e garotas contêm alto teor positivo atribuído ao Sol e a seus efeitos. Não comentaram nenhum aspecto negativo ou não tão positivo que pudesse estar associado a ele. Talvez isso se deva ao fato de as pessoas desse grupo, figurarem entre as que ficaram mais tempo freqüentando o Sol voluntariamente, por sentirem-se atraídas e seduzidas pelo que lá acontecia.

Outro ponto importante a ser comentado, é que as informações verbalizadas e exteriorizadas, gestual e corporalmente refletem muito a 
relação estabelecida com a educadora que participou e organizou o encontro. Essas falas ficaram com características dessa relação que mantêm e, inclusive por esse motivo, foram, de certo modo, bastante autênticas. Essa educadora é muito afetiva e demonstra essa afetividade abertamente. Não foi possível conhecer com mais detalhes a relação estabelecida entre eles (e cada um) e os demais educadores, apesar de terem perguntado especificamente por cada um deles e de terem sugerido um novo encontro reunindo todos educadores para que pudessem revê-los.

Entretanto, justamente pela qualidade da relação mantida entre essa educadora e o grupo e pela experiência de terem trabalhado juntos durante um certo período de tempo, foi que puderam falar com mais propriedade sobre os assuntos que lhes propusemos e outros que acharam conveniente comentar.

Esses jovens, falando hoje com o olhar voltado para o passado, mostram que experimentaram um sentimento de pertencimento que os vincula e os une; pertencimento a um grupo e a um lugar, que lhes serve de referência para a construção de identidades: pessoal e social. Diz Valquiria: "ó, (pra) falar a verdade, modéstia à parte falando, a nossa turminha daquela época marcou porreta, não foi? Foi demais!"

Mais do que "ocupar o tempo", Alcione prefere o termo "ocupar a cabeça", ao dizer sobre a influência do Sol na sua vida. E essa preferência por tal termo é crucial para a ênfase que ela quer dar na importância do que vivenciou. É uma pista que ela nos dá para podermos afirmar que o fato de "ocupar a cabeça" é maior e mais relevante do que "ocupar o tempo". Este pode ser preenchido com atividades variadas com o intuito de entretenimento e/ou de afastamento do pensamento de algo que perturba, que provoca, que tenta, mas tão logo a atividade acabe ou mesmo nos intervalos dela o pensamento volta a agir e é preciso buscar outra atividade para se fazer ou deixar-se cair nos "encantos" e "tentações" daquilo que se tenta fugir. O perigo do encontro com o Mefisto é que ele não é assustador, a princípio, mas que ele é sedutor e tentador e pode assumir qualquer forma; o medo aparece ao sentir-se envolvido por ele, ao ceder aos seus apelos.

"Ocupar a cabeça" é não dar tempo para pensar, mas é também envolvê-la com algo ao qual se atribui importância de modo a substituir um pensamento anterior; e nesse caso, é mudança de comportamento. Não indica fuga, mas uma atitude de comprometimento. 
Uma parte do tempo desses jovens foi vivida em comum, hoje, a vida de cada um deles tomou outros rumos. Com a chegada dos 14 anos, deixaram de freqüentar o Sol. Com a chegada dos 14 anos, da adolescência, outras necessidades, aspirações, expectativas passaram a ser as preocupações que motivavam suas buscas. E depois, outras preocupações e responsabilidades advindas da fase adulta.

Podemos notar duas importantes características nesse grupo: as garotas possuem maior grau de escolaridade, chegando até o nível colegial (com exceção de duas que pararam no final do ginásio) enquanto que um dos rapazes chegou até a oitava série do supletivo; a maioria das garotas não menciona estar trabalhando (uma está com emprego temporário e outra trabalha, eventualmente, trançando cabelos), o que implica dizer que preferiram fazer a opção pelo estudo ou pelo cuidado com família, enquanto que todos os rapazes dizem estar trabalhando, mas não estudando, mostrando que fizeram a opção pelo trabalho.

Esse grupo mostra que, de certa forma, estão bem inseridos na realidade social, ou seja, o trabalho, o nível de escolaridade e a ampliação deste, a constituição de família são valores que permeiam seus modos de viver.

Todas as pessoas que participaram do encontro - e que passaram grande parte de seu tempo no Sol -, ou estão trabalhando, ou estudando - ou desejando voltar a fazê-lo - ou estão procurando construir relações familiares estáveis. Entretanto, os próprios educadores já antecipam que alguns ex-freqüentadores acabaram sujeitando-se aos riscos do crime e da marginalidade, envolvendo-se com drogas. Esses mesmos educadores ouvem de ex-freqüentadores, que voltam para visitar o Sol e para reencontrarem-se, que a ida e permanência no Sol impediu que cedessem àquele chamativo.

As práticas educativas e as relações que acontecem nesse espaço criam laços fortes de envolvimento, afetividade e amizade, principalmente com os educadores, que faz com que esses sujeitos se interessem por visitá-lo, por rever esses adultos, por se informar sobre o que tem ocorrido lá, etc. Esse vínculo cria e fortalece o sentimento de pertencimento, que ajuda no processo de construção de identidade. A possibilidade de falarem de suas dúvidas, de expectativas, de aspirações, de frustrações, de necessidades, enfim, de socializarem seu cotidiano, aumenta a qualidade desse envolvimento e permite um maior comprometimento 
com o trabalho lá desenvolvido, tanto por parte dos educadores quanto das crianças e jovens.

O trabalho desenvolvido com ênfase nas linguagens artísticas (plásticas, teatrais, corporais, musicais), que têm sido bastante utilizadas nas práticas de educação não-formal, permite o aprofundamento do conhecimento da sensibilidade, o uso da criatividade e o exercício da criação, favorecendo a auto-expressão e estimulando a auto-estima. Esse procedimento adotado gera uma forma lúdica e prazerosa de pesquisa e descoberta no processo de construção do conhecimento.

A construção de sentido para a vida e os planejamentos em longo prazo me parecem ser a concretização do trabalho desenvolvido por esses projetos e programas. O direito e a permissão de se ter desejos e a posse de alguns instrumentos para buscar alcançá-los parece tornar-se a novidade no universo desses jovens e adultos. O que parece ter sido negado pelo social e por si mesmos adquire uma outra força, a de buscar uma melhora na qualidade de vida, ou seja, buscar a possibilidade de um certo exercício de cidadania dentro de um sistema econômico excludente, desigual e segregador, em que uma minoria se outorga o papel de cidadão com direito a ter direitos e imputa à grande maioria o papel de cumpridor de deveres.

Outro ponto que também merece menção é o fato, curioso, notado na fala do André que diz, no início da conversa, que não quer voltar a estudar pelo fato de não apreciar a escola e, horas depois, após ouvir a longa explanação do esportista e auxiliar de pedreiro Leônidas, muda seu discurso dizendo que vai voltar a estudar.

O que o motivou a mudar de idéia? Terá sido a sensação e a percepção de um investimento em algo que possa melhorar o futuro, que possa ter sido veiculado no discurso do Leônidas? Acredito que, possivelmente, sim. Ao chegar até aqui, conhecendo um pouco mais de perto as marcas que a vivência no espaço do Sol provocou na memória desse grupo de ex-freqüentadores e tomando contato com as direções que suas vidas tomaram - e que implicaram em escolhas e opções de caminhos -, podemos acreditar que as relações estabelecidas com o lugar, com as atividades, com as pessoas de diferentes idades e gerações, contribuíram sobremaneira para o que são hoje e, principalmente, no sentido de garantir-lhes uma possibilidade de empregarem seu tempo em algo e de "ocuparem suas cabeças" com saberes e conhecimentos que lhes são úteis para suas 
vidas que, em outras condições, talvez tivessem se voltado para formas mais imediatas de satisfazer os desejos e as necessidades provocadas pelo viver em sociedade, como eles mesmos comentam em conversas informais.

Da mesma forma que denunciam, veladamente, a falta de motivação para com a escola - ao fazerem breves comparações entre o que puderam vivenciar em um tipo de educação não-formal e em um tipo formal, qualificando aquela como altamente positiva e, ao deixarem de freqüentá-la antes de atingir os níveis mais altos de escolaridade - enxergam nela um meio que, talvez, lhes permita conquistar melhores condições de vida - em termos de emprego, salário e, posteriormente, aquisição de bens materiais de primeira necessidade (do tipo "quem casa quer casa") e de consumo. Apesar do desinteresse que a freqüência à escola lhes provoca, hoje, a grande maioria deles deseja voltar a estudar, como se quisesse dar uma "segunda chance" a ela. E nesse ponto, finalizando, gostaria de sugerir a inclusão de uma hipótese: não seria o tipo de experiência educacional vivenciada no Sol, qualificada como significativa, lúdica, agradável, prazerosa, a partir da descoberta e da construção conjunta de processos de conhecimento, ou seja, a presença de uma forma diferente de relacionamento criança-jovem-adulto e de se colocar em prática os processos educativos - em um aspecto mais amplo -, que contribuiria para criar um novo interesse pela escola, formando uma nova demanda de público para ela?

\section{Referências bibliográficas}

BRITO, Marilza E. Memória e cultura. Rio de Janeiro: Centro de Memória da Eletricidade no Brasil, 1989.

FERNANDES, Renata S. Contratempos e sobressaltos: os eclipses como fenômenos da natureza humana. Revista Resgate. Campinas, Unicamp/CMU, n. 10, p. 59-70, 2001.

GAGNEBIN, Jeanne M. Verdade e memória. Projeto História: os trabalhos da memória. São Paulo, EDUC/Fapesp, n. 17, p. 213-221, nov/1998.

GINZBURG, Carlo. Mitos, emblemas, sinais: morfologia e história. São Paulo: Companhia das Letras, 1989.

MAUAD, Ana M. História, iconografia e memória. In: SIMSON, Olga R. de M. von (org.). Os desafios contemporâneos da História Oral. Campinas: Unicamp/CMU, 1997, p. 309-320.

MONTEIRO, Rosa. A louca da casa. Rio de Janeiro: Ediouro, 2004. 
NORA, Pierre. Entre memória e história: a problemática dos lugares. Projeto História, n. 10, p. $7-28, \operatorname{dez} / 1993$.

Resumo: A partir de depoimentos de ex-freqüentadores e de educadoras de um projeto de educação não-formal, este texto apresenta e discute algumas situações que envolvem as lembranças e os esquecimentos provocados pelas relações estabelecidas com o local de freqüência, os suportes de memória materializados em produções e registros imagéticos, além de apresentar os portadores e os guardiões de uma memória individual e coletiva. Essas possibilidades de evocação e de socialização de um passado recente interferem nos modos como são reapresentadas no presente e como são projetadas no futuro.

Palavras-chave: memória e educação não-formal; memória de educadores; memória de jovens.

\section{Memory of Spaces, of Objects and the Guardians of Memories on Non- Formal Education}

Abstract: Starting from testemonies of former-visitors and educators of a nonformal education project, this text presents and discusses some situations that involve memories and forgetfulness. Those are caused by the established relationships with the frequency place, the supports of memory materialized in productions and registrations by images. Besides it presents the subjects that turn bearers and guardian of an individual and collective memory. Those evocation possibilities and socialization of a recent past interfere in the manners as the memories are represented in the present and as they are projected in the future.

Keywords: memory; non-formal education; memories of educators, memories of youth. 

